\title{
THE DOMESTIC LIVESTOCK RESOURCES OF TURKEY: SILKWORM (BOMBYX MORI, L. 1758) (LEPIDOPTERA: BOMBYCIDAE) LINES AND THEIR CONSERVATION
}

\section{Orhan Yilmaz ${ }^{1}$ \\ R. Trevor Wilson ${ }^{+}$}

\author{
'Vocational High School of Technical Sciences, Ardahan University, \\ Ardahan, Turkey \\ ${ }^{2}$ Bartridge Partners, Umberleigh, UK
}

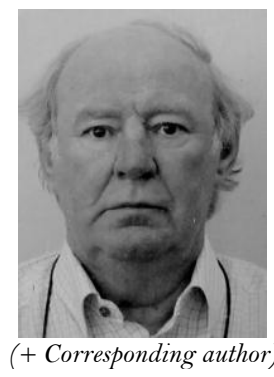

ABSTRACT

This paper reviews the current status of Turkish silkworm genetic resources and activities being undertaken for their conservation. Silk production and the trade in silk have been important activities in Turkey, which lies on the ancient Silk Road, for many hundreds of years. Current production of silk is on the rise after a period of very low production. Turkey has a well-established programme of conservation and development of all of its domestic animal genetic resources, of which silkworm is considered a constituent part. Three distinct lines of native silkworm have been registered with the national standards body, the Turkish Standards Institute. Distribution of silkworm germplasm is regulated by the Ministry of Food, Agriculture and Livestock through Cooperative Unions which have more than 10,000 members. Renewed and increased international demand for natural and biological products is favourable to Turkey's silkworm industry. The prognosis for the future development of silk production is strongly positive.

Contribution/ Originality: This study documents how silkworms have been kept in Turkey to produce silk as a value-added product for hundreds of years. They add diversity to household and national production. Three lines are being bred and conserved by Government institutions.

\section{INTRODUCTION}

Silk, produced naturally by the larva of the silkworm moth (Bombyx mori L. 1758; Lepidoptera, Bombycidae), accounts for only 0.2 per cent of world textile output but is produced in more than 60 countries across the world [1] and is an important contributor to household economies and to the income of women in many of these. China, Japan, Korea and India are the main producing countries although Japan and Korea have been reducing their supply whilst maintaining high demand. At a conference hosted by the Food and Agriculture Organization of the United Nations held in Thailand in 2002 purporting to review the silkworm genetic resources of the world only those four Asian countries and France, Italy and Bulgaria in Europe were covered [2] although many other countries, including Turkey, are known to have an array of silkworm genetic resources [1].

Silk has been produced and traded commercially in what is now the Republic of Turkey for many centuries. The Chinese traded silk - perfumes, jewellery, leather goods, spices and slaves - with the Hun Turks and began the history of what is now universally known as the Silk Road [3]. Many wars ensued over the years along the 10,000 $\mathrm{km}$ route as Chinese, Turks, Indians, Persians, Romans and Arabs sought to control it [4, 5]. The Selcuks built 
caravanserai along the Anatolian part of the Road at intervals of $30-40 \mathrm{~km}$ (7-8 hours of travel by camel) to facilitate trade [3]. The Byzantine Emperor Justinian sent two Nestorian monks to China as early as A.D. 552 to learn about sericulture and the production of silkworms and silk. Having learnt the technology they returned with eggs hidden inside bamboo canes [3, 6, 7]. Sericulture then became an important sector of the economy in the early Ottoman Empire along with wheat, grapes, opium and Angora hair [8]. Bursa in northwestern Anatolia -- the first Ottoman capital - was not only the most important city in Turkey for sericulture but was also a major transit point for the silk trade between Iran and Europe [9]. In addition to the Bursa area the provinces of Erzincan, Tokat, Diyarbakir and Amasya in Anatolia (Figure 1) and Aleppo in what is now Syria were and continue to be important production centres [10-13]. Although silk continues to be produced on a small commercial scale in five main areas in Turkey, silkworms are raised by as many as 40 per cent of primary school children as a hobby, along with ladybirds (Coccinellidae) and grasshoppers (Orthoptera) [14].

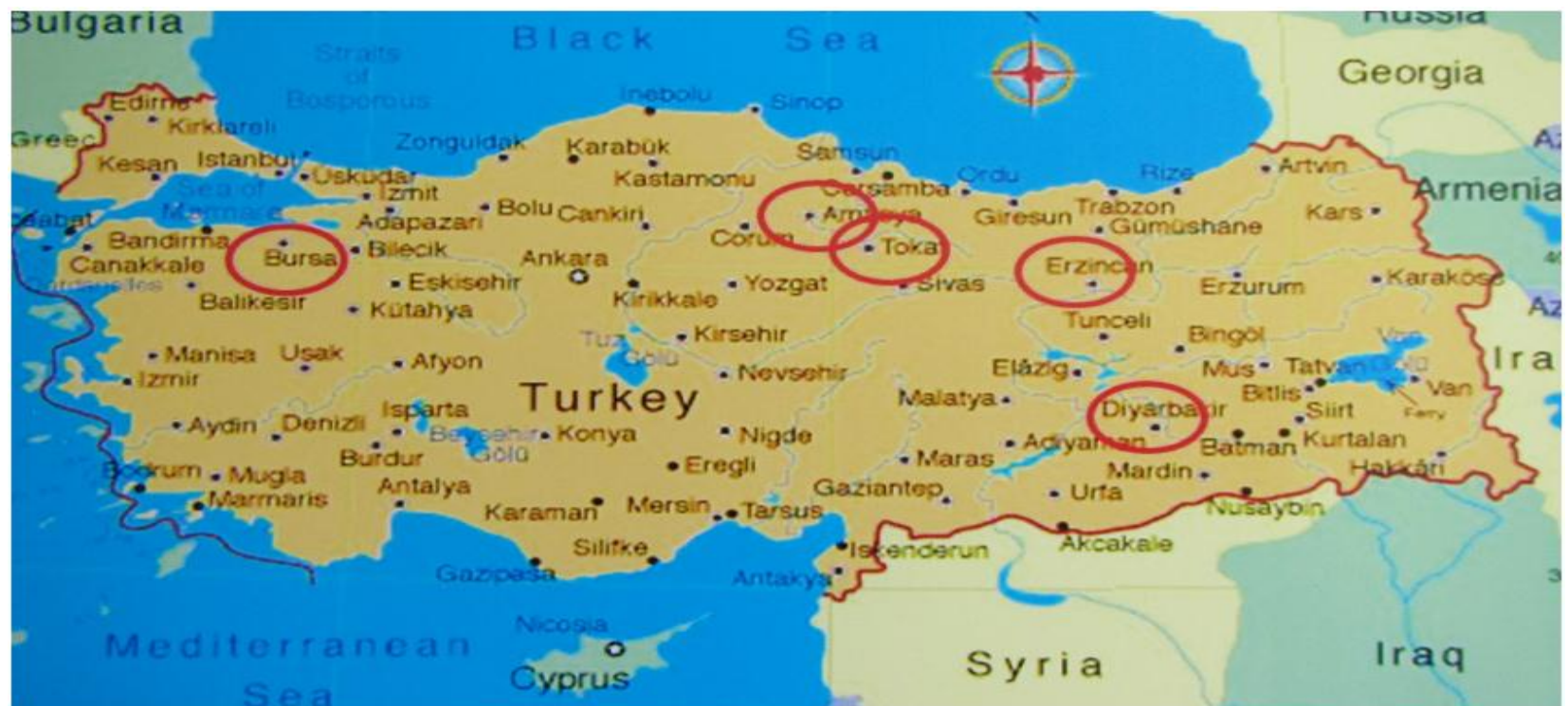

Figure-1. General map of Turkey showing past and present principal areas of silkworm production (Source: base map from www.maps.com)

This paper is one of a series on the domestic livestock of Turkey. It describes the local varieties of Bombyx mori and the measures being taken to develop and conserve them.

\section{GENETIC RESOURCES}

Economic problems in Turkey in the 1920s, and especially in 1929, resulted in reduced prices. The situation deteriorated further in the 1930 s as artificial fabrics were imported, mainly from East Asia. In the 1940s, Government tried to revive and support the silk industry by importing polyhybrid eggs that were to be used in place of the native monohybrid. In the 1970s and 1980s the fresh cocoon trade received further government support in attempts to develop local sericulture [9]. Turkey produced about 2000 tonnes of cocoons in the 1980s, falling to 130 tonnes in the 1990 s while domestic demand was about 400 tonnes [1]. In the year 2000 production fell to 60 tonnes, with a further fall to 47 tonnes in 2001 before some recovery to around an annual average of 150 tonnes took place through $2005[15]$

Three silkworm lines have been registered by the Turkish Standards Institution $[16,17]$ under Notice No 2004/39 published in the Official Gazette ('Resmi Gazete') Number 25668 of 12 December 2004. The native lines are Bursa White ('Bursa Beyazi', Figure 2), Bursa Piebald White ('Bursa Beyazi Alaca', Figure 3) and Hatay Yellow ('Hatay Sarisi', Figure 4). These lines have some common traits and some that differ (Table 1). The Random Amplified Polymorphic DNA (RAPD) technique was used to study genetic variation with 68 per cent of bands 
investigated by polymerase chain reaction (PCR). The highest ratio of polymorphic locus was 55.9 per cent in Hatay Yellow: 44.1 per cent was shown in both Bursa White and Bursa Piebald. Nei's genetic distance for Bursa White-Bursa Piebald was 0.0637, for Bursa White-Hatay Yellow was 0102 and for Bursa Piebald White-Hatay Yellow was $0.0793[18]$.

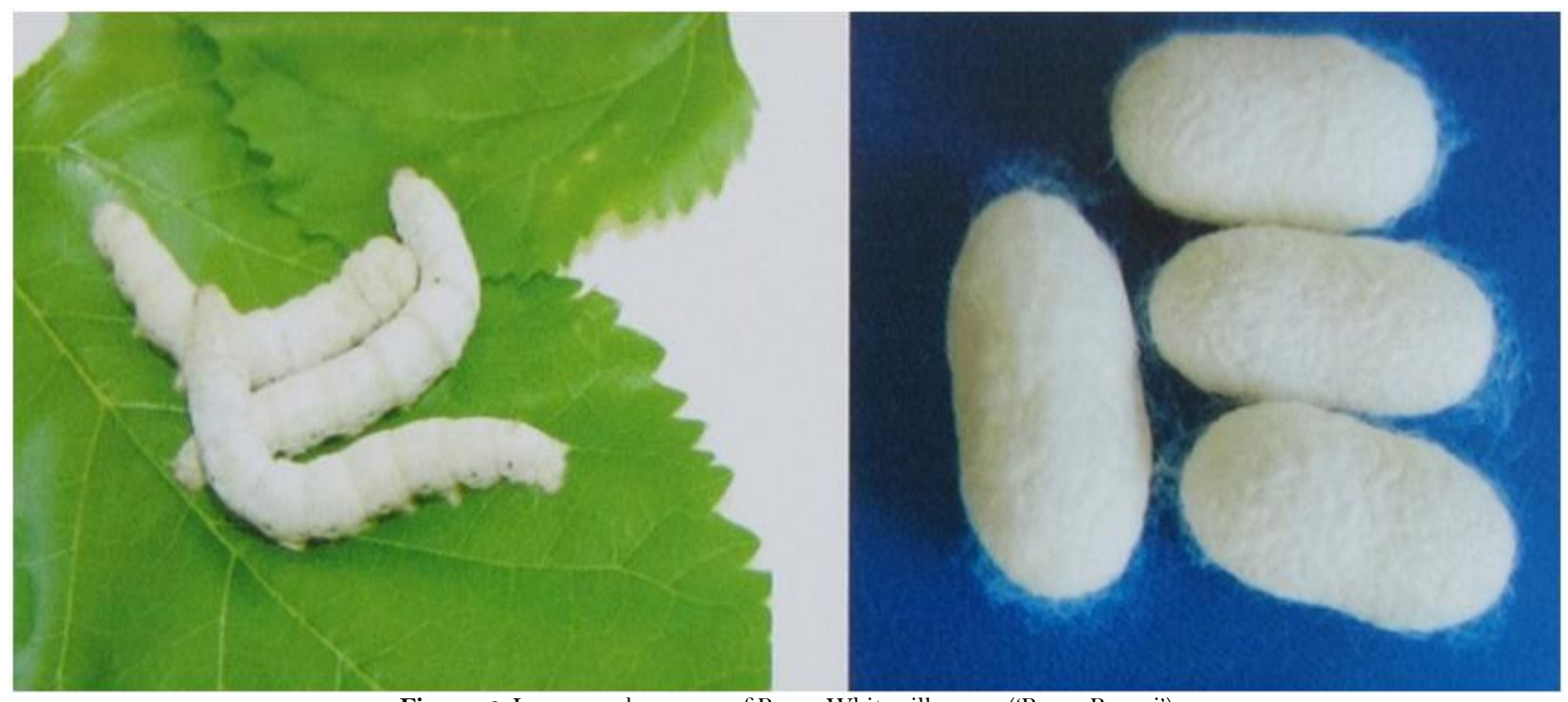

Figure-2. Larvae and cocoons of Bursa White silkworm ('Bursa Beyazi')
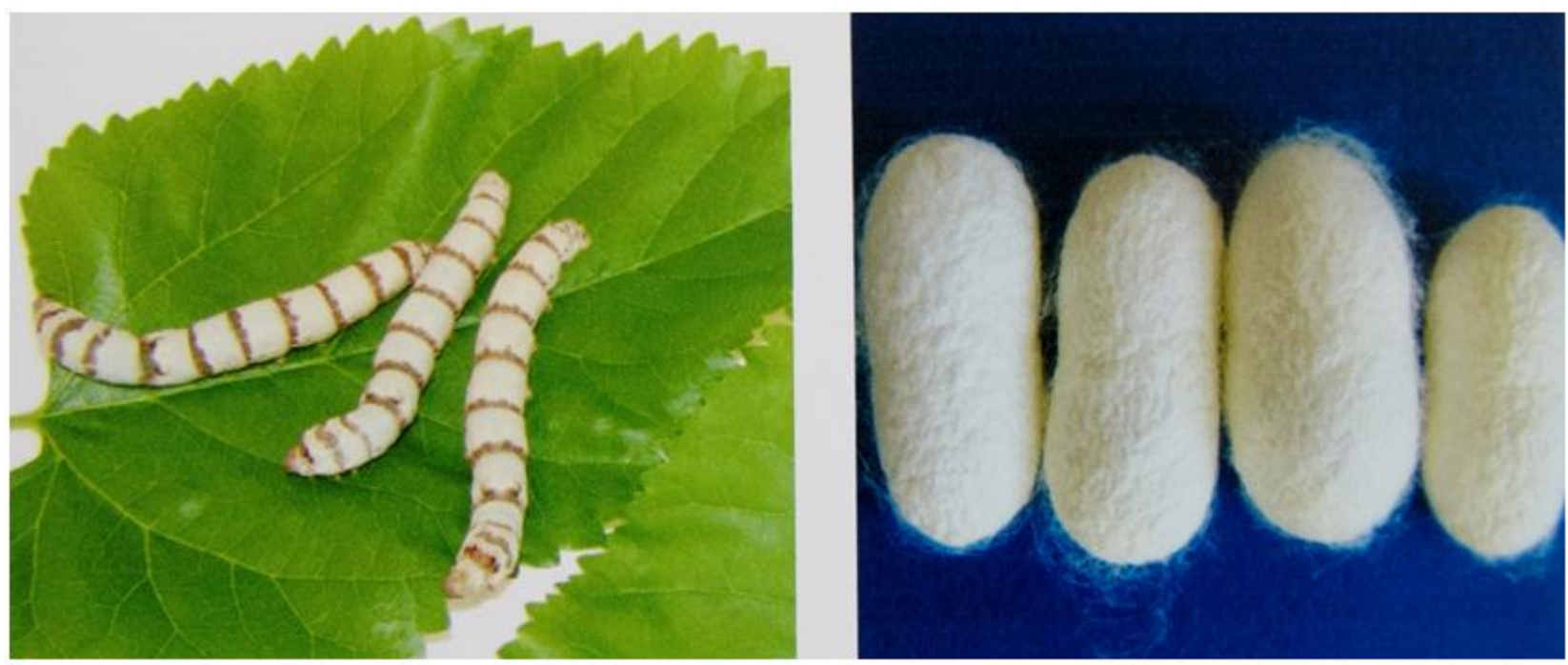

Figure-3. Larvae and cocoons of Bursa Piebald White silkworm ('Bursa Beyazi Alaca')
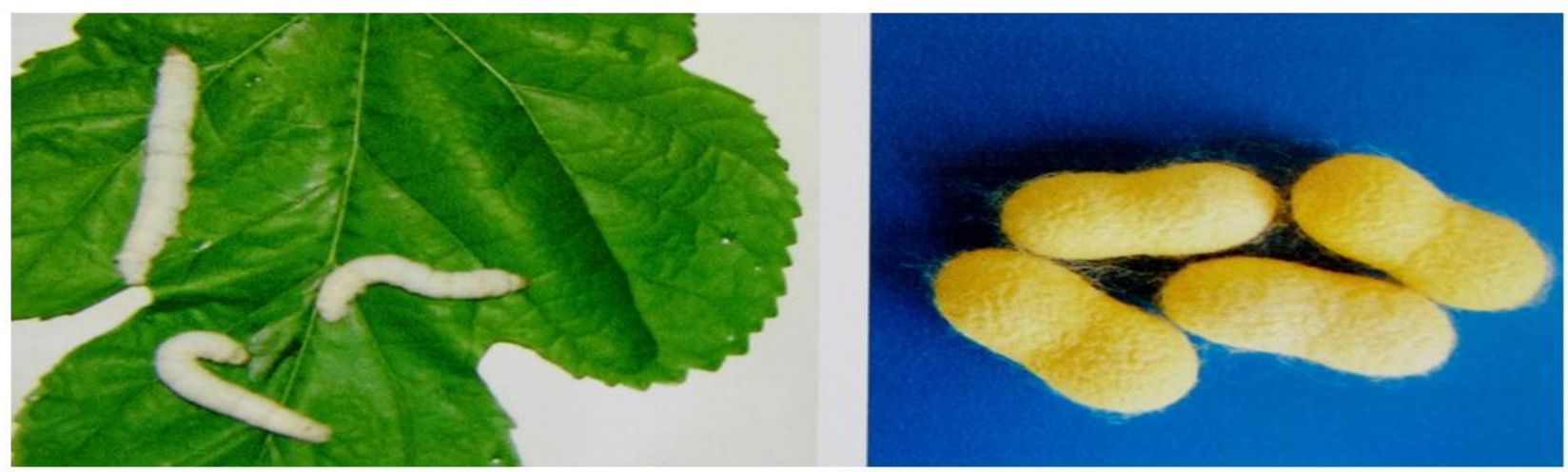

Figure-4. Larvae and cocoons of Hatay Yellow silkworm ('Hatay Sarisi') 
Table-1. Some characteristics of three silkworm lines being conserved in Turkey

\begin{tabular}{l|l|l|l}
\hline Trait & Breed & & \\
\hline & $\begin{array}{l}\text { Bursa White } \\
\text { ('Bursa Beyazi’) }\end{array}$ & $\begin{array}{l}\text { Bursa Piebald White } \\
\text { ('Bursa Beyazi Alaca') }\end{array}$ & $\begin{array}{l}\text { Hatay Yellow } \\
\text { ('Hatay Sarisi’) }\end{array}$ \\
\hline Voltinism & Univoltine & Univoltine & Univoltine \\
\hline Moultinism & Tetramoulting & Tetramoulting & Tetramoulting \\
\hline Egg shape & Elliptic & Elliptic & Elliptic \\
\hline Egg colour & Gray & Gray & Gray \\
\hline Number of eggs produced & $390-590$ & $439-656$ & $303-545$ \\
\hline Cocoon shape & Elliptic & Elliptic & Groundnut \\
\hline Cocoon colour & White & White & Orange \\
\hline Single cocoon weight $(\mathrm{g})$ & $1.25-2.16$ & $1.6-2.1$ & $1.4-2.1$ \\
\hline Ratio of cocoon:shell & $11.9-15.8$ & $13.3-15.7$ & $10.9-13.5$
\end{tabular}

Silkworm eggs were imported in limited quantities from Japan in 2002 and 2003 [15]. It is also reported that Turkey maintains 23 silkworm accessions and 15 mulberry tree accessions [19].

\section{CONSERVATION MEASURES}

During the period of the Ottoman Empire initiatives to promote and protect sericulture were made periodically and with varying success in the seventeenth to nineteenth centuries. Sericulture was given greater prominence, however, following the establishment of the Public Debts Institution in 1881 because it was able to contribute considerable revenue to the national treasury [20, 21]. An early piece of legislation in support of sericulture enacted by the Republic of Turkey Government after the overthrow of the Ottoman state was Act Number 859 "On the production, inspection and sale of silkworms and eggs" [22]. Under this law (which was the first relating to agriculture passed by the Turkish Government on 26 May 1926) was to define the procedure of silkworm activities in Turkey. The Ministry of Agriculture became the sole agency for producing, selling, distributing and inspecting the silk value chain: imports could only be made by the Ministry when deemed necessary, mulberry gardens would be established in locations defined by the Ministry and the Ministry was to construct sample workshops and an inspection laboratory in suitable locations. Cooperative unions were established in 1940 in Bursa, Bilecik and Adapazari to protect and increase cocoon production. These cooperatives were unified on 11 May 1940 as the Bursa Association of Agricultural Sales Cooperatives for Silk Cocoons (abbreviated as KOZABIRLIK). The Silkworm Egg and Cocoon Management Union was established in 1963 in order to produced silkworm eggs [23].

A conservation project for Turkey's domestic animal resources was initiated by the General Directorate of Agricultural Research and Policy in 1995. The primary objective was the characterization and conservation of breeds at risk. Cattle were the only species included at the start of the project in 1995 but the programme was broadened in 1996 and 1997 to include sheep, goat, buffalo, domestic fowl and silkworm in 1996 and 1997: bees were included in 2002. A second animal genetic resources project entitled "In vitro Conservation and Preliminary Molecular Identification of Some Turkish Domesticated Animal Genetic Resources - I" was set up in 2007 and concluded at the end of 2011 although silkworms were not included in this project [17, 24].

Conservation and development activities continue at Bursa Provincial Directorate of Agriculture [24, 25]. Sericulture is supported by a system whereby government subsidizes prices paid by the Bursa Association of Agricultural Sales Cooperatives for Silk Cocoons (KOZABIRLIK; the only formal producer organization in the country with 10,881 members in five smaller cooperatives). Producer prices and subsidies vary via a grading system comprising Breeding, Grades 1 to 3 and Ungraded. Subsidies have provided a large part of producer income in recent years $[15,26,27]$.

Law No 5996 of December 2010 "The Veterinary Services, Phytosanitary, Food and Feed Law” puts in place the powers to license food production establishments in technical and hygienic terms and to establish an efficient 
audit and control system [28, 29]. In addition, however, two regulations introduced under this law cover conservation and promotion of domestic animal resources: these are Conservation of Animal Genetic Resources and Animal Breed Registration. These regulations establish two formal bodies, being the "National Consultative Committee on Conservation of Animal Genetic Resources" and the "Animal Breed Registration Committee” [17]: it can be expected that these two committees will continue to monitor existing and future domestic animal diversity as their mandates include identifying objectives and policies on conservation, on sustainable use, on characterization and on import and export operations.

\section{DISCUSSION}

Silk production and trade have long been important activities in the Middle East and Central Asia and have been linked with the Silk Road for hundreds of years. Varying support has been provided by the governments of the greater region for these activities but the diversity of the silkworm and it value to the economy has long been a hostage to fortune. The advent of cheaper man-made fibres and silk substitutes rendered the position of sericulture and its associated activities of spinning and weaving somewhat precarious. Production was reduced and there was undoubtedly considerable loss of valuable silkworm genetic resources as a result. Most countries, nonetheless, maintained stocks of native lines and there was trade and exchange in these. Turkey, although a relatively small producer, has contributed to this genetic diversity and both informal and formal exchanges or transfers have taken place. One formal example is that of Italy which imported four lines from Turkey in 1995 [30]. Italy also imported silkworm eggs from Turkey in 1998, 1999 and 2002 [15].

Attitudes to the use of man-made fibres have been changing and there is increasing demand within "developed" countries for natural and biological products of which silk is an example. The economic standards of European populations (at least outside the period of recession in the second half of the decade of the 2000s) also encouraged the use of such products in spite of higher prices.

The Near East and Central Asia regions and Turkey in particular (especially with the long term likelihood of membership of the European Union and already favourable terms of access to the EU market) are well placed geographically to supply this market. The creation of the Black, Caspian Seas and Central Asia Silk Association in 2005 [31] was partly in response to this horizon with one of its main objectives being the production, maintenance and transfer of sericultural germplasm and silkworm eggs.

Turkey has already taken positive steps to identify, maintain and improve its silkworm genetic resources. Its commitment to all its domestic animal resources is adequately demonstrated through its various research stations and projects. The prognosis for its silkworm resources can thus only be favourable.

Funding: This study received no specific financial support.

Competing Interests: The authors declare that they have no competing interests.

Contributors/Acknowledgement: The original photographs for Figures 2, 3 and 4 are courtesy of S. Isik of the General Directorate of Agricultural Research and Policy, Ministry of Food, Agriculture and Livestock.

\section{REFERENCES}

[1] R. K. Datta and M. Nanavaty, Global silk industry: A complete source book. New Delhi, India: APH Publishing, 2007.

[2] FAO, "Conservation status of sericulture germplasm resources in the World - II." Conservation status of silkworm (Bombyx Mori) Genetic Resources in the World (Papers contributed to Expert Consultation on Promotion of Global Exchange of Sericulture Germplasm, Bangkok, Thailand; September 2002) (compiled by Kee-Wook Sohn). Rome: Food and Agriculture Organization of the United Nations, 2003.

[3] G. Kirpik, "Haclilar ve Ipek Yolu [The Crusades and the Silk Road]," Bilig: Turk Dunyasi Sosyal Bilimler Dergisi, vol. 61, pp. 173-200, 2003. 
[4] A. Toprak, "Doğu- Batı Kültürel Etkile şiminde İpek Yolu (Başlangıçtan Gökt ürk D önemi Sonuna Kadar) [The Silk Road in the cultural interaction of East and West (from the beginning to the end of the Gokturk Period) (Unpublished M.Sc. Thesis)," Sosyal Bilimler Enstitusu, Gazi Universitesi Ankara, 2008.

[5] A. Sahin and S. Cengiz, "16’nci Yüzyil Fiyat Devrimi ve Osmanli Iran Savaslarinin Osmanli Ipekçilik Endüstrisi Üzerine Etkileri," Isletme ve Ekonomi Arastirmalari Dergisi, vol. 1, pp. 69-82, 2010. View at Google Scholar

[6] N. A. Gunay, "Yavuz Sultan Selim'in Ipek Ambargosu [The embargo on silk of Yavuz Sultan Salim]," Bursa'da Yasam Dergisi, Aralik, pp. 166-173, 2013.

[7] H. Tas, "Bursa Folklorunda Ipek ve Koza [The folklore of cocoons and silk in Bursa]. Bursa'da Yasam Dergisi," Aralik, pp. 136-147, 2013.

[8] N. E. Bayram, "1837-1923 sürecinde Bursa’da ipekçilik sektörünün sosyo-ekonomik analizi," Fen Edebiyat Fakultesi, Uludag Universitesi, Sosyal Bilimler Dergisi 2013/1, vol. 14, pp. 45-58, 2013. View at Google Scholar

[9] M. Ersevinc, "19-20 Yuzyillarda Bursa'da Ipekcilik [Sericulture in Bursa in the nineteenth and twentieth centuries]," Bursa'da Yasam Dergisi, Aralik, pp. 92-101, 2013.

[10] D. Altun, "XIX Yüzyilda Bursa'da Épek Böcekçiligi [Sericulture in Bursa in the nineteenth century], Balikesir Universitesi," Fen Edebiyat Fakultesi Karesi Tarih Kulubu Bulteni, vol. 1, pp. 102-108, 2007.

[11] W. Hunter, "Bursa Mektubu - Mayis 1792 (Cev: Ekiz, C. ve Ulutas, C.) [A letter from Bursa of 1792 (from C Ekiz and C Uluas)]," Bursa'da Yasam Dergisi, Aralik, pp. 396-401, 2013.

[12] A. Soysaldi and H. A. Ozdemir, "Bursa Kiz Ceyizinde Ipegin Yeri [Silkworm girls' dowries in Bursa]. Bursa'da Yasam Dergisi," Aralik, pp. 156-165, 2013.

[13] H. Yucekaya, "Amasya Ipekçiligi Üzerine (1750-1900)," Gazi Akademik Bakis Dergisi, vol. 13, pp. 269-284, 2013. View at Google Scholar

[14] S. Tezcan, F. Tezcan, N. Gulpercin, A. O. Karababa, A. Kanlioglu, A. Uzum, N. Tanyeri, F. Yolcu, N. D. Ozcan, I. Ilhan, R. Duman, A. Onucar, A. K. Birgucu, M. Atalay, V. Eraslan, S. Oruc, T. Baybora, and M. C. Ersoy, "Toplumda Böcek FarkindaligiYaratılmasında BÖFYAP Projelerinin Yeri [The importance of BOFYAP Projects in raising the awareness of insects in the society of Turkey]," Biyoloji Bilimleri Arastirma Dergisi, vol. 3, pp. 101-106, 2010.

[15] Turkish Statistical Institute, Silkworm sector questionnaire. Ankara: Turkish Statistical Institute. Retrived from: http://www.abgs.gov.tr/tarama/tarama_files/11/sorular_cevaplar_files/cevaplar/Ipekbocegi.pdf Accessed 25 June $2015,2005$.

[16] Anon, Terli Hayvan Irk Ve Hatlarinin Tescili Hakkinda Teblig, [Registration of Domestic Animal Breeds]. Ankara: Resmi Gazete Number 25668, 2004.

[17] GDAR, Domestic animal genetic resources in Turkey. Ankara: General Directorate of Agricultural Research and Policy, Ministry of Food, Agriculture and Livestock, 2011.

[18] D. E. Akkir, F. A. B. Yildiran, and S. S. Cakir, "Molecular analysis of three local silkworm breeds (Alaca, Bursa Beyazi and Hatay Sarisi) by RAPD-PCR and SDS-PAGE methods," Kafkas Universitesi Veteriner Fakultesi Dergisi, vol. 16, pp. 265-269, 2008. View at Google Scholar

[19] P. I. Tzenov, "Present status for utilizing of sericultural genetic resources in some Eastern European and Central Asian Countries." Retrieved: http://www.bacsa-silk.org/en/sericulture-germplasm-in-bacsa-countries/. [Accessed 28 June 2015 ], 2015.

[20] Z. Dortok-Abaci, "Éngiliz Konsolosluk Belgeleri Işiginda Bursa Ekonomisi (1848-1896)," Sosyal Bilimler Dergisi, vol. 7 , pp. 159-171, 2006. View at Google Scholar

[21] M. A. Yildirim, "Düyûn-I Umûmiyye İdâresi’nin Kurulmasindan Sonra Osmanli’da Kozaciliğin (İpekböcekçiliğinin) Gelişimine Dair [On the development of sericulture production following establishment of the Public Debts Institution]," Mustafa Kemal Universitesi Sosyal Bilimler Enstitusu Dergisi, vol. 10, pp. 65-83, 2013. View at Google Scholar

[22] Anon, Ipek Böcegi Ve Tohumu Yetistirilmesi Ve Muayene Ve Satilmasi Hakkinda Kanun [Law on the production, inspection and sale of silkworms and eggs]. Ankara: Resmi Gazete, Number 402, 1926. 
[23] Anon, "Yili Ipek böcegi raporu [Silkworm Reports]. Akara: General directorate of cooperatives," Ministry of Customs and Trade, 2013.

[24] S. Arat, "In Vitro conservation and preliminary molecular identification of some Turkish domestic animal genetic resources (Turkhaygen-I)," presented at the Powerpoint Presentation at the Eighth Global Conference on the Conservation of Animal Genetic Resources, 4-8 October.2011, Tekirdag, Turkey, 2011.

[25] M. Ertugrul, G. Dellal, C. Elmaci, A. O. Akin, E. Pehlivan, M. I. Soysal, and S. Arat, "Ciftlik Hayvanlari Genetik Kaynaklarinin Kullanilmasi ve Surdurulebilir Kullanimi [Conservation of Farm Animal Genetic Resources and their Sustainable Use]," presented at the Turkish Agricultural Engineering Technical Congress VII, Ankara, 2010.

[26] Anon, Yas Koza Destekleme Bakanlar Kurulu Karari, sayili 28612 [Council of Ministers' Decision in Support of Silk Production]. Ankara: Resmi Gazete, Number 28612, 2013.

[27] S. Baysal, "Ipekbocegi Yeniden 'Inficar'a Hazirlaniyor [The silkworm is preparing for breeding again]," Bursa'da Yasam Dergisi, Aralik, pp. 190-195, 2013.

[28] Anon, Veteriner hizmetleri, bitki sagligi, gida ve yem Kanunu [Law on veterinary services, phytosanitary, food and feed]. Ankara: Resmi Gazete, Number 27610, 2010.

[29] European Parliament, Briefing for the ENVI delegation to Turkey. Food safety and public health situation in Turkey. Brussels: European Union, 2010.

[30] S. Cappellozza, "S. 7. Conservation status of bombyx mori (Silkworm) Genetic resources in Italy. Conservation Status of Sericulture Germplasm Resources in the World - II.," presented at the Conservation Status of Silkworm (Bombyx Mori) Genetic Resources in the World (Papers Contributed to Expert Consultation on Promotion of Global Exchange of Sericulture Germplasm, Bangkok, Thailand; September 2002) (compiled by Kee-Wook Sohn). Unpaginated. Food and Agriculture Organization of the United Nations, Rome, 2002.

[31] BACSA, "Black, caspian seas and central Asia silk association." Retrieved from: http://www.bacsa-silk.org/en/whoare-we/. [Accessed 25 June 2015], 2005. 